\title{
オゾン酸化したポリプロピレン繊維へのメタクリル酸 メチルの気相グラフト共重合
}

（1991 年 7 月 19 日 受 理）

\author{
松 井哲 治*
}

ポリプロピレン繊維をオゾン酸化することにより活性点を生成し，これにメタクリル酸メチルを気相 でグラフト共重合し，気相グラフト共重合に関する基礎的な知見を得るとともに，通常の液相法とのグ ラフト共重合挙動の違いを調べた。また, 両者の枝ポリマーの分子量, 分岐数などのグラフト体の構造 を調べ, これらと結晶化度, 複屈折, 機械的性質および DSC の融解挙動などとの関連性について調べ た。その結果，つぎのことが判明した。

気相法によっても夜相法と同様にメタクリル酸メチルのグラフト共重合が可能である。また, 両者は そのグラフト率がオゾン酸化時間, 重合時間および重合温度とともに增加するのに対して, グラフト効 率は減少するなどグラフト共重合挙動においては同じ傾向を示した。グラフト率はオン゙ン酸化時間が短 い間は液相法の方が大きいが，2 時間程度でほぼ等しくなるのに対し，雨者のグラフト効率はこれらと はかかわりなくほぼ等しい。ほぼ同じグラフト率をもつ試料の構造には, 気相法によって得られたグラ フト体の枝ポリマーの分子量が液相法のものより小さいが，分岐の数は多いといら相違点が見いだされ た。この違いはグラフト体の結晶化度, 複屈折, 機械的性質, DSC の融解挙動にも現れている。この 事実は気相グラフト共重合法ではグラフト化が纎維表面近傍で進み, 内部はほとしど変化していないこ とを示唆するものである。

\section{1 緒言}

著者らはポリェチレン，ポリプロピレン (PP) などのポリオレ フィンをオゾン酸化し，オゾン酸化機構を提案した121。また，こ れらにメタクリル酸メチル（MMA）をグラフト共重合してグラ

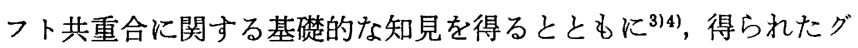
ラフトポリマーの結晶構造 ${ }^{56)}$ とついても報告した。これらのグラ フトポリマーの合成法は通常の夜相で重合する方法（液相法）で ある。この液相法に対して，モノマーを気相でグラフト共重合す る方法（気相法）があり， r線照射したポりマーに気相でグラフ ト共重合する多くの報告がある7) 99。また，荻原らは気相法に

神戸市立工業高等専門学校, 651-21 神戸市西区学園東町

** 姫路工業大学, 671-22 姫路市書写

1) J. Yamauchi, A. Yamaoka, K. Ikemoto, T. Matsui, Bull. Chem. Soc. Jpn., 64, 1173(1991).

2) J. Yamauchi, K. Ikemoto, A. Yamaoka, Makromol. Chem., 178, 2483(1977).

3) J. Yamauchi, A. Yamaoka, K. Ikemoto, T. Matsui, J. Appl. Polym. Sci., 43, 1197(1991).

4）山岡昭美, 池本勲治, 松井哲治, 山内 淳, 日化, 1989, 1919.

5）山岡昭美, 松井哲治, 池本綮治, 日化, 1991， 75 .

6) 松井哲治, 山岡昭美, 日化, 1991, 1108.

7）潒原煡一，高松俊昭，高分子，10，819(1961).

8）川瀬 德, 早川 浄, 日化, 1972, 1938.

9) K. Kawase, K. Hayakawa, J. Polym. Sci, Part A-1, 7, 3363(1969).
よる光グラフト共重合がフィルム表面の改質に有効であること を報告している(10) 12)。これらの報告では気相法と液相法のグラ フト体に㧊けるグラフト鎖の位置については報告例はあるもの の ${ }^{13 \sim}$ 15), 両法に拈けるグラフト休の構造と物性との関係につい ての報告は見当らない。

本研究ではオゾン酸化して活性点を生成したPPに MMAを 気相でグラフト共重合し, 気相グラフト共重合に関する知見を得 るとともに，同条件の液相法の結果と比較検討した。また，両者 の枝ポリマーの分子量, 分岐数などのグラフト体の構造を調べ, これらと結晶化度, 複屈折, 機械的性質书よび DSC に上る融解 挙動などとの関連性についても調べた。その結果, 両者のグラフ ト体の構造に違いが見られたので, これらの結果を報告する。

10) Y. Ogiwara, M. Kanda, M. Takumi, H. Kubota, $J$. Polym. Sci. Polym. Lett. Ed., 19, 457(1981).

11) H. Kubota, N. Yoshino, Y. Ogiwara, ibid, 21, 267 (1983).

12) Y.Ogiwara, H. Kubota, ibid., 23, 365(1985).

13) J. Okamoto, T. Sugo, A. Katakai, H. Omichi, $J$. Appl. Polym. Sci., 30, 2967(1985).

14) H. Kubota, N. Koike, Y. Ogiwara, J. Polym. Sci., Part C, Polym. Lett., 25, 273(1987).

15) H. Kubota, Y.Hata, J. Appl. Polym. Sci., 41, 689 (1990). 


\section{2 供試試料および実験方法}

\section{1 供試試料}

グラフト共重合に用いた PP 繊維は市肘のアイソタクチックタ イプ（分子量 $1.92 \times 10^{5}$, 密度 0.894 ) の粉末を 2.4 デニールの 繊維に紡系したものである。この中に含まれる酸化防止剂を除去 するために, ソックスレー抽出器で 48 時間アセトンで抽出を行 った。メタクリル酸メチル（MMA）は市肘品を常法により精製 した。

\section{2 実験方法}

2.2.1 オソンン酸化：オゾンは酸素気流中の無声放電により発 生させ, 試料をオゾン気流中 (濃度 $30 \mathrm{~g} / \mathrm{m}^{3}$ ) $30^{\circ} \mathrm{C}$ で所定時間酸 化した。

2.2.2 グラフト共重合法: 気相グラフト共重合法はつぎのと おりである。すなわち，オゾン酸化した PP 試料 $0.1 \mathrm{~g}$ （重量 $W_{1}$ ) を図 1 の重合管（気体状のモノマーが自由に通過でき，凝縮 したモノマーが底にたまらないよらなポリェチレン製のかご）中 に保持した。常法により 3 回窒素置換を行い, 減圧にしたまま滴 下漏斗より MMA $4 \mathrm{ml}$ (重量 $W_{2}$ ) を滴下し（直接試料にあたら ないよらに容器を伝わって落下するようにする）気体状とした。 所定温度で所定時間グラフト共重合を行った。なお, グラフト共 重合中の温度は熱電対温度計で常時監視した。重合管中の生成物 を乾燥（重量 $W_{3}$ ）し，アセトン中で 6 日間 1 日 1 回溶媒を取替 え煮沸しホモポリマーを除去した。この時の非抽出物をグラフト 体（重量 $W_{4}$ ）とみなし, 次式によりグラフト率 $(D G)$ およびグ ラフト効率 $(G E)$ を算出した。

$$
\begin{aligned}
& D G=\frac{W_{4}-W_{1}}{W_{1}} \times 100(\%) \\
& G E=\frac{W_{4}-W_{1}}{W_{3}-W_{1}} \times 100(\%)
\end{aligned}
$$

液相グラフト共重合法はつぎのとおりである。すなわち，オゾ ン酸化した PP 試料 $0.1 \mathrm{~g}$ (重量 $W_{1}$ ) を試験管に入れ，MMA モノマー $4 \mathrm{ml}$ (重量 $W_{2}$ )を加えて, ドライアイス/メタノール中 で涷結させ, 常法により 3 回窒素置換をした。内容物を室温で融 解し, 所定温度で所定時間グラフト共重合した。重合終了後, 水 冷して反応を停止し, 生成物を多量のメタノール中で沈殿させ, 沪過乾燥した（重量 $W_{3}$ )。つぎに, アセトン中で 6 日間 1 日 1 回 溶媒を取替えながら煮沸し，ホモポリマーを除去した。この時の 非抽出物をグラフト体（重量 $W_{4}$ ）とみなし, 気相法と同様 (1) 式扰よび（2）式によりそれぞれ $D G$ 打よび $G E$ を算出した。

2.2.3 分子量の測定（粘度法による）之分岐数の算出：木モ ポリマーの粘度は Ubbelohde 型粘度計でメチルェチルケトンを

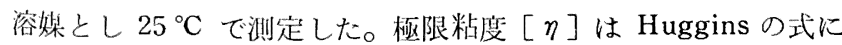
より求めた。たたし，Huggins の定数は $k^{\prime}=0.39$ を用いた ${ }^{16)}$ ついで, ホモポリマー(PMMA) の分子量は次式により求めた。

$$
[\eta]=0.71 \times 10^{-4} \times M^{0.72}
$$

PP 幹ポリマーの粘度は Ubbelohde 型粘度計を用い, テトラ リンを溶媒として，135 ${ }^{\circ} \mathrm{C}$ で測定し，極限粘度 [ $\left.\eta\right]$ は Huggins の式から求めた。ただし, Huggins の定数 $k^{\prime}$ は 0.36 を用

16) S. N. Chiani, J. D. Matlack, A. L. Resnick, R. Samuels, J. Polym. Sci., 17, 391(1955).

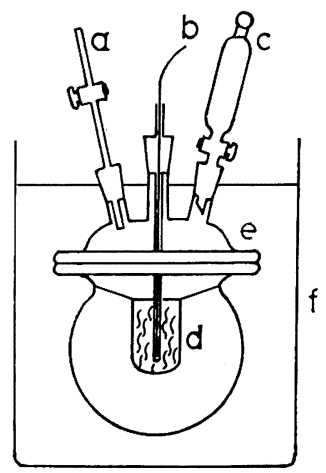

Fig. 1 The apparatus of vapor-phase graft copolymerization

a : Two-way cock, b : Thermocouple,

c : Trap funnel, d : Polyethylene basket, e : Separable flask, $f$ : Constant-temperature water bath

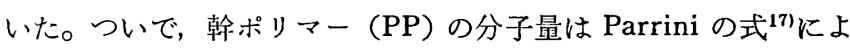
り求めた。

$$
[\eta]=0.80 \times 10^{-4} \times M^{0.80}
$$

分岐数 $(N B)$ は枝ポリマーと幹ポリマーのモル比で, 枝ポリマ 一とホモポリマーの分子量が等しいと仮定し, 次式により求め た。

$$
N B=D G \times \frac{M W_{\mathrm{t}}}{M W_{\mathrm{h}}} \times 10^{-2}
$$

$D G:$ グラフト率 $(\%)$

$M W_{\mathrm{t}}:$ 幹ポリマーの分子量

$M W_{\mathrm{h}}:$ ホモポリマーの分子量

2.2.4 幹ポリマーの結晶化度の測定 : グラフト PP 幹ポリマ 一の結晶化度の測定には既報5) と同様に理学電機(株)製自記記録 装置を用い，反射集中法で測定した。測定条件はつぎの通りであ る。

$\begin{array}{ll}\text { Tube voltage } & 30 \mathrm{kV} \\ \text { Tube current } & 15 \mathrm{~mA} \\ \text { Scanning speed } & 0.5^{\circ} \mathrm{min}^{-1} \\ \text { Sganning angle } & 2 \theta=5 \sim 40^{\circ}\end{array}$

PP の結晶化度は Natta ら ${ }^{18)}$ の方法に準じて空気散乱補正を行 った回折曲線を非晶部分と結晶部分に分離し, 次式によって算出 した。

結晶化度 $(\%)$

$$
\begin{aligned}
& =\frac{3.06 A_{110}+5.18 A_{040}+6.89 A_{130}+10.30 A_{111}}{\left(3.06 A_{110}+5.18 A_{040}+6.89 A_{130}+10.30 A_{111}\right)+6.21 A_{\mathrm{a}}} \\
& \times 100
\end{aligned}
$$

ただし， $A_{110}, A_{040}, A_{130}, A_{111}$ は各結晶ピークの面積, $A_{\mathrm{8}}$ は非 晶部分の面積である。

グラフト共重合体中の幹ポリマーの回折強度曲線の分離はつぎ

17) P. Parrini, Markromol. Chem., 38, 27(1960).

18) G. Natta, P.Corradini, M. Cerari, Rond. Acca. Ne:. Lincei, 8, 22(1957). 
のよらにして行った。まず空気散乱補正をしたポリメタクリル酸 メチル (PMMA) の回折強度曲線から, 次式により算出される相 似比から相似曲線が得られる。

$$
\text { 相似比 }=\frac{W_{\mathrm{I}} \cdot I_{\mathrm{I}}}{W_{\mathrm{I}} \cdot I_{\mathrm{I}}+W_{\mathrm{II}} \cdot I_{\mathrm{II}}}
$$

$W_{\mathrm{I}}:$ グラフト体中の PMMA の重量分率

$W_{\mathrm{II}}:$ グラフト体中の幹ポリマーの重量分率

$I_{I}$ : 原子構造因子および Compton 散乱から決まる PMMA の計算強度

$I_{\text {III }}$ 幹ポリマーの計算強度

この曲線を空気散乱補正を行ったグラフト体の回折強度曲線か ら引くことにより, 幹ポリマーの回折強度曲線が得られる。この 曲線により幹ポリマーの結晶化度を算出した。

2.2.5 複屈折度の測定法 : 複屈折は偏光顕微鏡 POM 型（才 リンパス光学(株)社製) を使用し, Berek のコンペンセーターを 挿入して測定した。たたし, 光源はナトリウムランプを使用し, 浸液はツェーデル油である。

2.2.6 機械的性質測定法 : 東洋精機(株)製 TENSILON III型 を用い, 加重一伸長率曲線を測定し, Young 率, 切断強度および 伸度を測定した。測定条件はつぎの通りである。

$\begin{array}{ll}\text { Room temperature } & 21{ }^{\circ} \mathrm{C} \\ \text { Relative moisture } & 65 \% \mathrm{rh} \\ \text { Sample length } & 20 \mathrm{~mm} \\ \text { Tensile speed } & 20 \mathrm{~mm} \mathrm{~min}^{-1}\end{array}$

2.2.7 DSC の測定 : Perkin-Elmer 社の DSC-1 B 型示差走 差熱量計（DSC）を用い，窒素雲囲気下で測定した。測定条件は つぎの通りである。

$\begin{array}{ll}\text { Sample weight } & 10 \mathrm{mg} \\ \text { Scanning speed } & 10{ }^{\circ} \mathrm{C} \mathrm{min}-1 \\ \text { Range } & 8 \mathrm{mcal} \mathrm{s}^{-1}\end{array}$

\section{3 実験結果および考察}

\subsection{PP 繊維への気相グラフト共重合}

3.1.1 グラフト共重合挙動におよぼすオソン酸化時間の影 響：所定時間オゾン酸化した PP 繊維に, MMA を $80^{\circ} \mathrm{C} て ゙$ 所定 時間気相グラフト共重合した時のグラフト率 $(D G)$ およびグラ フト効率 $(G E)$ を図 2 に示す。

オゾン酸化していないPP 綫維はほとんどグラフト共重合しな いが，オゾン酸化時間とともに $D G$ は増加した。この理由はつ ぎのように考えられる。すなわち，既報でオゾン酸化によって生 成するヒドロペルオキシドがオゾン酸化時間とともに增加するこ とを述べた2)6。このヒドロペルオキシドの熱分解によって生じる アルコキシルラジカル（RO・）はグラフト共重合の開始点となる が，これがオゾン酸化時間とともに増加すると予想されるためで ある。

$$
\begin{aligned}
& \mathrm{RH}+\mathrm{O}_{3} \longrightarrow \mathrm{ROOH}+\mathrm{O}_{2} \\
& \mathrm{ROOH} \longrightarrow \mathrm{RO} \cdot+\cdot \mathrm{OH}
\end{aligned}
$$

一方, $G E$ はオゾン酸化時間とともに減少している。この理由 はつぎのように考えられる。すなわち、グラフト共重合拈よび単

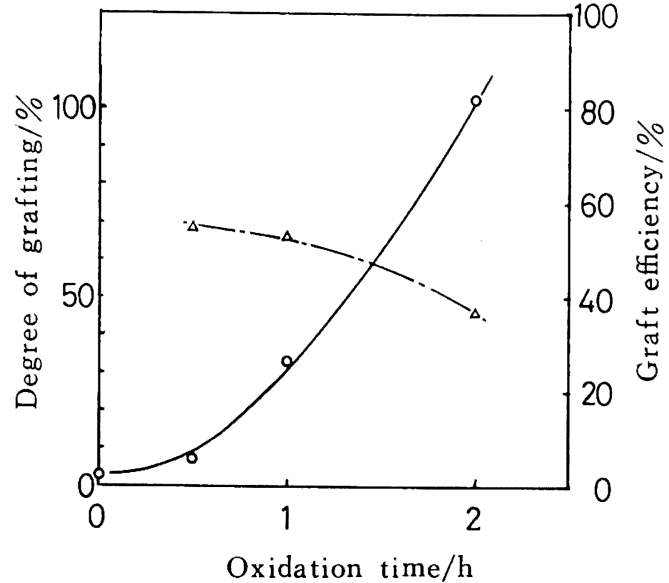

Fig. 2 Degeee of grafting and graft efficiency plotted against ozone-oxidation time

Polymerization conditions : $80^{\circ} \mathrm{C}, 1 \mathrm{~h}$

$\bigcirc:$ Degree of grafting, $\triangle:$ Graft efficiency

独重合はともにポリマー中に生成したヒドロペルオキシドからの アルコキシルラジカルとヒドロキシルラジカルからそれぞれ開始 する。このオゾン酸化が主として試料表面から進行するために， オゾン酸化初期では表面のみにヒドロペルオキシドが生成し，そ の後次第に内部にもヒドロペルオキシドが生成するよらになる。 このうち表面に生成したアルコキシルラジカルおよびヒドロキシ ルラジカルは, 比較的容易にモノマーと反応するが, 内部に生成 したアルコキシルラジカルはポリマー中に存在するために外部へ 拡散しにくく反応性が低い。それに対して，内部に生成したヒド ロキシルラジカルはアルコキシルラジカルとくらべて拡散しやす く, 外部へ出てモノマーと反応する機会が相対的に多くなる。そ の結果ホモポリマーが多く生成し，GE が減少するものと思われ る。

3.1 .2 グラフト共重合挙動におよぼす重合時間の影響：1 時 間オゾン酸化した PP $80^{\circ} \mathrm{C}$ で所定時間 MMA を気相グラフ 卜共重合した時の $D G$ および $G E$ を図 3 に示す。

重合時間が長くなるにつれて， $D G$ は大きくなっている。これ

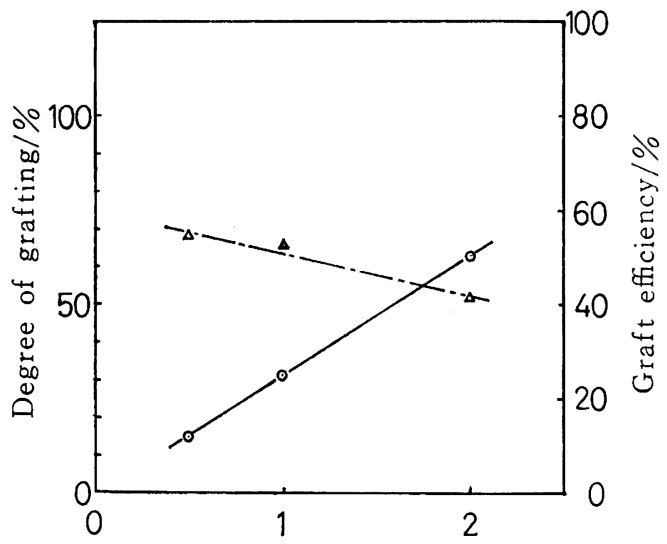

Polymerization time/h

Fig. 3 Degree of grafting and graft efficiency plotted against polymerization time

Ozone-oxidation time : $1 \mathrm{~h}$, Polymerization temp.: $80^{\circ} \mathrm{C}$ $\bigcirc:$ Degree of grafting, $\triangle:$ Graft efficiency 
は重合時間とともにグラフト鎖が成長していることを意味する。 一方, $G E$ は重合時間とともに減少している。これはグラフトポ リマーは一端を固定されて拈り, 重合が進むにつれて周りをホモ ポリマーに囲まれてくるのでモ, マーが拡散浸透しにくくなり, グラフトポリマーの生成が少なくなるのに対して, 外側にあるホ モポリマーへはモノマー蒸気が拡散浸透しやすいため, 相対的に ホモポリマーが多くなると思われる。

3.1.3 グラフト共重合挙動におよばす重合温度の影響： 2 時 間オゾン酸化した PP に所定温度で 2 時間 MMA を気相グラフ ト共重合した時の $D G$ および $G E$ を図 4 に示す。

重合温度が高くなるにつれて $D G$ は急增し, $G E$ は減少してい る。また， $60^{\circ} \mathrm{C}$ では $D G$ は極めて低くほとんど重合していな い。これは $80^{\circ} \mathrm{C}$ とくらべると $60^{\circ} \mathrm{C}$ では MMA の飽和蒸気圧 が低く, 温度による反応性の違いのほかに, 重合容器内に存在す るモノマー量が半減（0.55）していることも大きく影響したため と思われる。したがって，DG が反応温度とともに急增するの は, 重合温度が高いほど反応に関与するモノマー量が増えること も影響している。 $G E$ が温度とともに減少する理由はつぎよう に考えられる。すなわち、ヒドロキシルラジカルから成長するホ モポリマーは，MMA モノマーが温度上昇とともに拡散しやすく なるために順調に成長する。一方,アルコキシルラジカルから成 長するグラフトポリマーは, 後述するように主として PP 織維表 面近修で成長するものの, グラフト化の進行には PP 内部へのモ ノマーの拡散浸透を必要と寸る。このPP 内部へのモノマーの拡 散浸透は温度が高くなるにつれて幾分かは容易になるものの，木 モポリマー内部への拡散浸透とくらべると制約を受けるものであ ろら。このよらに温度上昇とともに順調に成長するホモポリマー にくらべて，グラフトポリマーの成長の程度が相対的に低くなる ためと思われる。

\section{2 気相法と液相法との比較}

3.2.1 グラフト共重合挙動の比較 : 前項で詳述した気相法と 一般的なグラフト共重合法である液相法と比較するために, 所定 時間オゾン酸化した PP に MMA を $80^{\circ} \mathrm{C} て ゙ 2$ 時間グラフト共 重合を行った。その結果を図 5 および図 6 に示す。

気相法は液相法にくらべて, 短時間オゾン酸化した試料の $D G$ は低いが， 2 時間でほぼ同じ值となっている。この理由の一つ は, 気相法ではグラフト共重合開始点であるアルコキシルラジカ ル近傍でのモノマー浱度が液相法にくらべて低いことが挙げられ る。また, ヒドロペルオキシド濃度が低く, その分解生成物であ るアルコキシルラジカル濃度も低いと考えられる短時間オン゙ン酸 化した試料は，グラフト共重合および単独重合とも進行度合いは 低いが，オゾン酸化時間が長くなるにつれてアルコキシルラジカ ル䠞度が高くなり，液相と同様にグラフト共重合が進みやすくな るためと思われる。

$G E$ において液相法と父相法の間に差異がなく, アルコキシル ラジカルとヒドロキシルラジカルの反応性がモノマー賑度に製関 係であることを示している。このように気相法のグラフト共重合 挙動は液相法とよく似ている面があるが, 気相法に拈いては拡散 するのはモノマーであり，ポリマーラジカルの昖散はさほど重要 な要因でないように思われる。

3.2.2 グラフト体の構造の違い:つぎに, 二つの方法によっ て得られるグラフト体の棈造の違いを分子量と分岐数の視点から

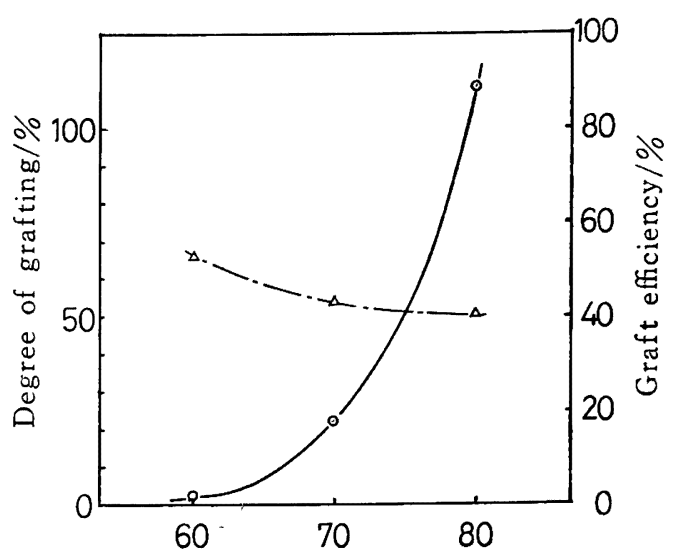

Polymerization temp. $/{ }^{\circ} \mathrm{C}$

Fig. 4 Degree of grafting and graft efficiency plotted against polymerization temperature

Ozone-oxidation time : $2 \mathrm{~h}$, Polymerization time $: 2 \mathrm{~h}$ $O$ : Degree of grafting, $\triangle:$ Graft efficiency

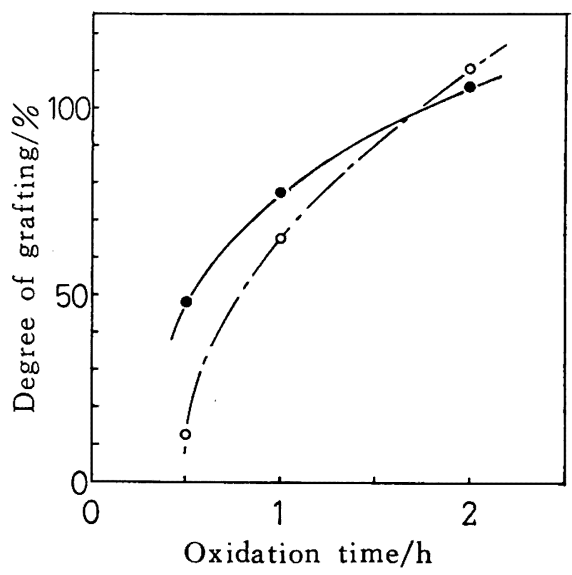

Fig. 5 Degree of grafting for two polymerization methods plotted against ozone-oxidation time

Polymerization conditions: $80^{\circ} \mathrm{C}, 2 \mathrm{~h}$

$\bigcirc$ : Vapor-phase method, : Liquid-phase method

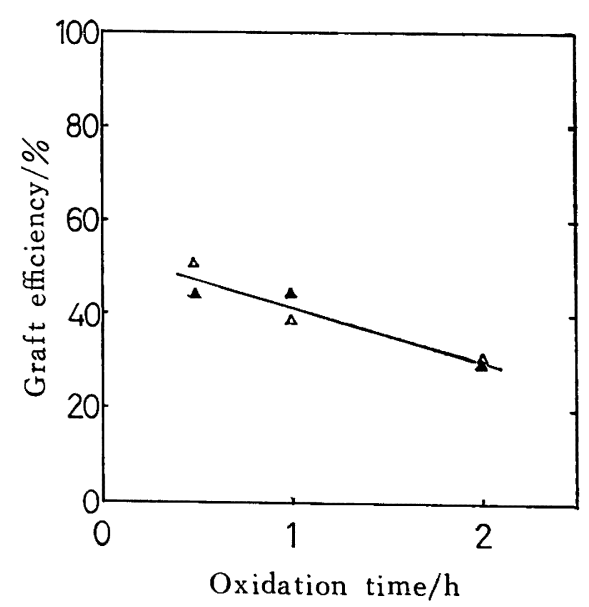

Fig. 6 Graft efficiency for two polymerization methods plotted against ozone-oxidation time

Polymerization conditions: $80^{\circ} \mathrm{C}, 2 \mathrm{~h}$ $\triangle:$ Vapor-phase method, $\mathbf{\Delta}:$ Liquid-phase method 
Table 1 The molecular weight of homopolymer and the number of branch for MMA-grafted polypropylene fiber

\begin{tabular}{|c|c|c|c|}
\hline $\begin{array}{l}\text { Polymerization } \\
\text { method }\end{array}$ & $\begin{array}{l}\text { Degree of } \\
\text { grafting } \\
(\%)\end{array}$ & $\begin{array}{l}\text { Molecular } \\
\text { weight } \\
\left(\times 10^{6}\right)\end{array}$ & $\begin{array}{c}\text { Number of } \\
\text { branch } \\
\left(\times 10^{-2}\right)\end{array}$ \\
\hline \multirow{3}{*}{ Vapor-phase } & 14.9 & 1.33 & 0.74 \\
\hline & 32.2 & 1.86 & 1.14 \\
\hline & 64.1 & 2.18 & 1.94 \\
\hline \multirow{3}{*}{ Liquid-phase } & 22.6 & 2.12 & 0.70 \\
\hline & 51.2 & 2.40 & 1.14 \\
\hline & 77.6 & 3.15 & 1.62 \\
\hline
\end{tabular}

Polymerization conditions : $80^{\circ} \mathrm{C}, 2 \mathrm{~h}$

比較した。グラフト体の枝ポリマーの分子量は直接測定できない ので副生するホモポリマーの分子量を測定した。また, 分岐数は ホモポリマーの分子量と枝ポリマーの分子量が等しいと仮定して 算出し，それらの結果を表 1 に示す。

二つの方法ともホモポリマーの分子量のオーダーは $10^{6}$ と大き く, 気相法の分子量が夜相法のそれよりやや小さいという結果を 得た。この理由はつぎのよらに考えられる。すなわち, 液相法で はモノマー分子が PP 内部へ拡散浸透するのに対し, 気相法では その割合が液相法にくらべて少ない。この結果, 繊維やフィルム への液相グラフト共重合では比較的表面付近でグラフト共重合が 進むが，気相法ではそれらよりなお表面近傍でグラフト共重合が 進行するのではないかと思われる。荻原ら ${ }^{12}$ は増感剤を用いた光 グラフト共重合においては， $\gamma$ 線のような高エネルギー照射でな いために，グラフト共重合反応が表面に限定されることを電子顕 微鏡で確かめている。本実験に用いたオゾン酸化法によっても， その酸化条件を制御し，かつ気相でグラフト共重合することによ り, 表面付近に限定したグラフト共重合が可能であると思われ る。

また，分岐数に関しては気相法の方が液相法より大きく，短い 枝が多くグラフトした構造をしていることを示している。

つぎに, この分岐数の違いがグラフト体の物性に扣よぼす影響 を調べるために, 結晶化度扣よび複屈折を測定し, それぞれ図 7 および図 8 にその結果を示す。

結晶化度はグラフト率の増加とともに若干減少しており, グラ フト化の進行によって少々ではあるが結晶構造が破壊されたこと を示している。また, 気相法と液相法の比較では, 気相法の結晶 化度の低下が小さいことがわかる。この理由も両方のグラフト鎖 の位置の違いからくるものであろら。

複屈折は試料の光学異方性の程度, すなわち結晶相と非晶相を とりまとめた分子鎖の配向の程度の指数である。グラフトPP の 複屈折は $D G$ が大きくなるにつれて低下している。これはグラ フト化が進むにつれて非晶性の PMMA 側鎖が導入されること により複屈折が低下したものである。また，二つの方法で得られ たグラフト体の複屈折をくらべると, 気相法の方が複屈折の低下 の割合が小さい。これは気相法が夜相法より試料付近のモノマー 濃度が低く，また，繊維内部へのモノマーの拉散浸透の困難さか ら試料表面近傍のみにグラフト化が限定されやすく, 内部は変化 しにくいためではないかと思われる。

3.2.3 グラフト織維の機械的および熱的性質の違い: 二つの 方法で得られた MMA グラフト PP 繊維のグラフト構造の違い

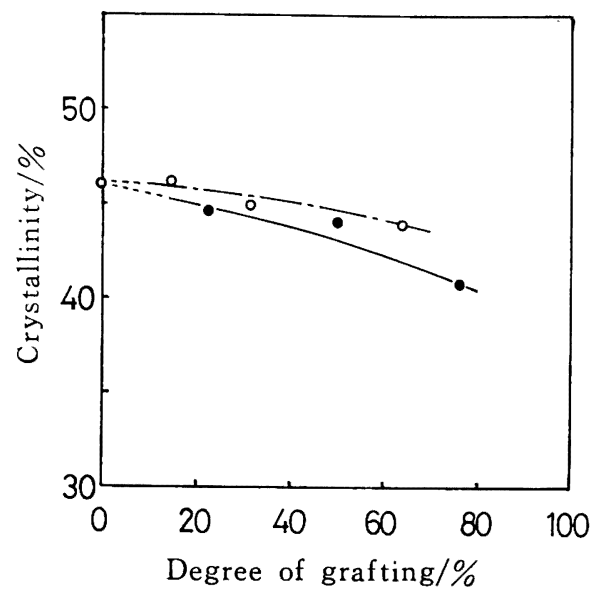

Fig. 7 Crystallinity of polypropylene for two polymerization methods plotted against degree of grafting

$\bigcirc$ : Vapor-phase method, $\mathrm{:}$ Liquid-phase method

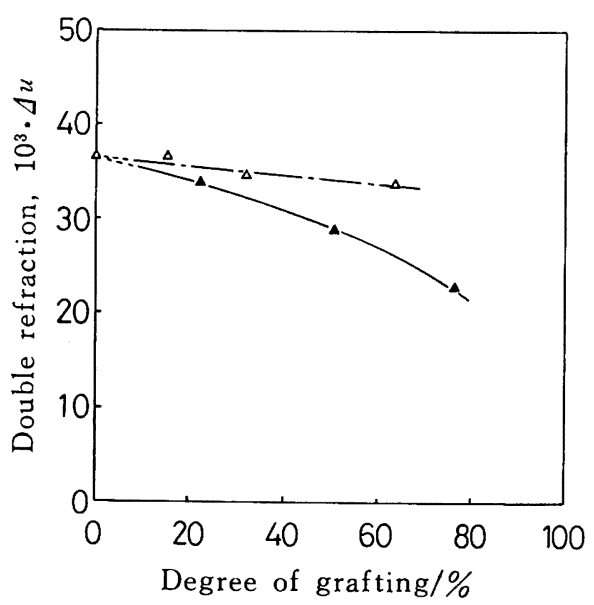

Fig. 8 Double refraction of MMA-grafted polypropylene fibers for two polymerization methods plotted against degree of grafting

$\triangle:$ Vapor-phase method, $\boldsymbol{\Delta}:$ Liquid-phase method

が物性にどのよらに反映されるかを確かめるために機械的性質を 測定し，その結果を表 2 に示す。

気相法の切断強度は低 $D G$ のものではグラフト前より低下し ているが， DG $64.1 \%$ のものでは元と変らないまで強度が回復 している。この原因はオゾン酸化により PP 分子鎖が切断され強 度が低下するが，低 $D G$ ではグラフト化による強度の増加の効 果が低いためにグラフト前より低くなっており，DG $64.1 \%$ 程 度までグラフト化が進むことにより元の強度まで回復したものと 思われる。このことはオゾン酸化したPP 繊維の経時変化を調べ ればわかる。今回の報告はこれらについての詳細な記述は省略寸 るが， 0.5 時間オン゙ン酸化した PP 繊維を 20 日常温で放置した 後の強度は約 $7 \%$, 伸度は約 $23 \%$ 低下している。本実験のグラ フト共重合においては,オゾン酸化試料は $80{ }^{\circ} \mathrm{C} て ゙ 2$ 時間程度お かれていることから，グラフト共重合中も若干の劣化が起こって いるものと考学られ，低 $D G$ に敃いてグラフト前より強度が低 下したものと思われる。一方, 液相法で得られたグラフトポリマ 一の切断強度は, 低 $D G$ では気相法とほぼ同じでグラフト前よ 
Table 2 The mechanical properties of MMA-grafted polypropylene fiber

\begin{tabular}{|c|c|c|c|c|}
\hline $\begin{array}{c}\text { Polymerization } \\
\text { method }\end{array}$ & $\begin{array}{l}\text { Degree } \\
\text { of } \\
\text { grafting } \\
(\%)\end{array}$ & $\begin{array}{c}\text { Tensile } \\
\text { strength } \\
\left(\mathrm{g} \mathrm{d}^{-1}\right)\end{array}$ & $\begin{array}{l}\text { Elonga- } \\
\text { tion } \\
\text { at break } \\
(\%)\end{array}$ & $\begin{array}{l}\text { Young's } \\
\text { modulus } \\
(\mathrm{kg} \cdot \\
\left.\mathrm{mm}^{-2}\right)\end{array}$ \\
\hline \multirow{3}{*}{$\begin{array}{l}\text { Original fiber } \\
\text { Ozone-oxidized } \\
\text { fiber }\end{array}$} & 0 & 4.96 & 38.3 & 270 \\
\hline & 0 & 3. 76 & 15.3 & 296 \\
\hline & 14.9 & 3. 30 & 14.1 & 348 \\
\hline \multirow[t]{3}{*}{ Vapor-phase } & 32.2 & 3.25 & 14.3 & 355 \\
\hline & 64.1 & 3.87 & 15.9 & 401 \\
\hline & 22.6 & 3.66 & 15.0 & 386 \\
\hline \multirow[t]{2}{*}{ Liquid-phase } & 51.2 & 3.85 & 16. 6 & 433 \\
\hline & 77.6 & 3.97 & 18.1 & 484 \\
\hline
\end{tabular}

Ozone-oxidation time : $1 \mathrm{~h}$, Polymerization temp. $: 80^{\circ} \mathrm{C}$

り低下しているが，その後 $D G$ とともに增加し気相法のものと 差がなくなっている。

つぎに，伸度についても切断強度とほぼ同じ傾向が見られる。 これに対して Young 率は $D G$ とともに大きく増大して拈り，そ の傾向は液相法の方が大きい。Young 率の増加は PP にくらべ て硬いポリマーである PMMA がグラフト共重合したためであ る。また, 気相法の Young 率の増加が小さいのは, 気相法のグ ラフト鎖の位置が液相法のそれより繊維表面近傍に限定されるこ とにより,グラフト前後の結晶構造の変化が少ないためと思われ る。

つぎに, これらのグラフト体の融解挙動を DSC で測定し, 図 9 に示す。

この融解曲線は二つの融解ピークをもっている。オゾン酸化し た PP 繊維のオゾン酸化時間とその DSC 曲線に見られる融解举 動の関係については別の機会に詳述するが，オゾン酸化時間とと もに両ピークとも低温側にシフトし, その程度は高温側ピークの 方が大きい。また, 低温側のピーク面積は増加しているが, 高温 側のそれは減少している。これらの事実から, 粉末の場合5) と同 様とみなすと, 低温側のピークはオン゙ン酸化によって分子鎖が切 断されたものの, その後の昇温過程で厚化したラメラの融解に相 当する部分であり, 高温側ピークが元の結晶の融解に相当するも のと考学られる。気相法の両ピークの位置および面積はオゾン酸 化試料と大差なく，グラフト化が表面近傍のみで進むものと考え られることから，この程度の $D G$ のグラフト化では内部の結晶 構造への影響は少ないものと思われる。一方, 液相法では高温ピ ーク温度はオゾン酸化試料と変化がないが, 低温ピーク温度が少 し高くなっている。これは液相法ではこの程度の $D G$ のグラフ ト化によってもラメラの厚化が起こりにくくなったことを示して いる。また，ピーク面積も小さくなってグラフト化によっていく ぶん絬晶構造が破壊されたことを示している。以上のよらに, DSC の融解挙動からも, 気相法と液相法では得られるグラフト 体の構造に違いがあることを示していると考劣られる。

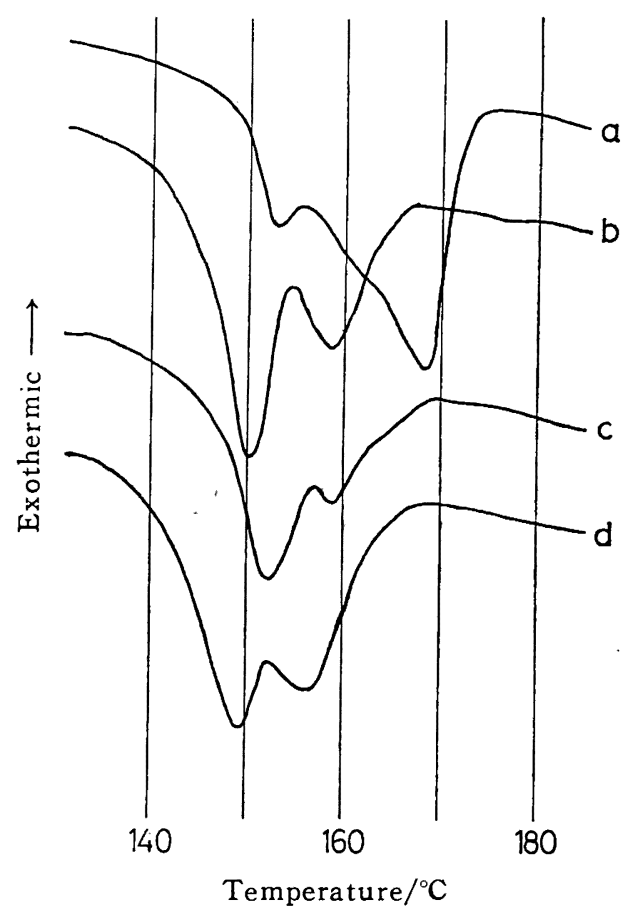

Fig. 9 DSC curves for various polypropylene fibers

a : Original, b : Ozone-oxidized fiber for $1 \mathrm{~h}$, c : MMA-grafted fiber ( $D G 77.5 \%$, liquidphase method), d : MMA-grafted fiber ( $D G$ $64.1 \%$, vapor-phase method)

\section{4 結 論}

オゾン酸化した PP 繊維に気相法で MMA をグラフト共重合 したところつぎの結論が得られた。

（1）気相法によってもオゾン酸化 PP 緘維への MMA のグ ラフト共重合が可能であり, その機構は液相法の場合と同じであ ると思われる。

（2）気相法グラフト业重合において，DG はオゾン酸化時 間, 重合時間または重合温度とともに増加するが, $G E$ は減少す る。

（3）気相法と液相法にくらべると，オゾン酸化時間の短い試 料では $D G$ は液相法の方が大きいが，オゾン酸化 2 時間でほぼ 同じ值となる。GEはオゾン酸化時間に無関係に両者に差がな W。

（4）ほぼ同じグラフト率をもつ試料をくらべると, 枝ポリマ 一の分子量は液相法の方が大きく, 分枝数は気相法の方が大き い。これらの違いは結晶化度, 複屈折, 機械的性質および DSC の融解挙動にも現れている。

（5）以上のことを総合すると, 気相グラフト共重合ではグラ フト化が繊維表面近傍で進み, 内部はほとんど変化していないこ とが推測される。 


\title{
Vapor-Phase Graft Copolymerization of Methyl Methacrylate onto Polypropylene Fiber Oxidized with Ozone
}

\author{
Tetsuji MAtsui* and Akiyoshi YamaOKA** \\ Kobe City Colledge of Technology; Gakuen Higashimachi, Nishi-ku, \\ Kobe-shi 651-21 Japan \\ ** Himeji Institute of Technology; Shosha, Himeji-shi 671-22 Japan
}

After the activation of polypropylene fiber by ozone-oxidation, methyl methacrylate was graft copolymerized onto it. The ability of the activated fiber to initiate vapor-phase graft copolymerization was compared with that of usual liquid-phase one. The structural differences between the graft copolymers (vapor- and liquid-phase samples) prepared by the vapor-phase graft copolymerization method and the liquid-phase one were discussed from the data of the mechanical properties, the crystallinity, the double refraction, and the melting behavior by DSC.

The degree of grafting for the vapor-phase sample increased with the ozone-oxidation time, the polymerization time, and the polymerization temperature, while the graft efficiency decreased. These tendencies were the same as those for the liquid-phase one. The number of branch for the vapor-phase sample was higher than that for the liquid-phase one, but the molecular weight of branch estimated by that of homopolymer was lower. The mechanical properties were improved by vapor-phase grafting and liquid-phase one, and the extent of which was small for the vapor-phase sample. The decreases in the crystallinity and the double refraction for the vapor-phase sample was less than that for the liquid-phase one.

These facts suggest that the vapor-phase graft copolymerization proceeds near fiber surface in our experimental conditions. 